\title{
COMMENT
}

\section{ERNST FREUND AS A TEACHER OF LEGISLATION $\dagger$}

\author{
MaURICE T. VAN HeCKE*
}

I AM TEMPTED to open this statement with an affectionate portraiture of Ernst Freund, the man. Mindful of his modesty, I shall yield only long enough to recall his old-world courtliness, his gentle kindness, his spirited gayety and quick humor, his tremendous intellectual vigor, and the universality of his scholarship. Never "one of the boys," he touched the hearts of his students.

I cannot attempt to write of Mr. Freund's many years of work with the civic groups of Chicago, and before the city council, the Illinois General Assembly, and the Constitutional Convention of I920. It was Miss Harriet Vittum, I believe, head of Northwestern University Settlement, who described him some years ago as one of the most useful men in Chicago.

Partly because Mr. Freund once wistfully confessed that he had never read an understanding review of one of his books, I wish I might have felt competent to evaluate his writings: the influential Police Power, intended, he modestly said, as a practitioner's handbook, written almost entirely out of the notes in the Lawyers' Reports Annotated, in a downtown law library on the one day a week he was free from class engagements; his stimulating Standards of American Legislation, regarded by its author merely as a series of impressionistic notes, but which in rgr8 was to win the Ames Prize; the compendious legislative manual constituting the r92I Report of the Special Committee of the American Bar Association on Legislative Drafting, almost exclusively Mr. Freund's work, later to become in part the basis for his last book, the definitive treatise on Legislative Regulation, and its companion volume, the comprehensive study of $A d$ ministrative Powers over Persons and Property. His many articles in legal periodicals I cannot even mention specifically. Instead of attempting an evaluation of his writings, I should like to speak of Mr. Freund's teaching of the course in Statutes. This, like the course in Administrative Law, was peculiarly his own creation. Never in nearly twenty years was it taught twice with the same materials or with the same emphasis. He was never willing to embalm the course in a casebook.

Mr. Freund deliberately chose to teach the two hours immediately following

$\dagger$ An address delivered at the annual meeting of The Association of American Law Schools, Chicago, Illinois, December, I932.

* Dean of The School of Law, the University of North Carolina. 
lunch. Yet his passionate eagerness and dynamic enthusiasm for his subject made these classes, particularly the one in Statutes, the intellectual climax of . each student's day. Not, however, that we claimed at that time that we understood him fully. Or that he made us content. On the contrary, we emerged from the class in Statutes uncomfortable, confused and bewildered. Most of us had spent more than two years in the orderly process of tracing the intricate designs of the mosaic of judge-made law, carefully laid down in the historical-approach casebooks of the period. But Mr. Freund swept us from the German Civil Code to the English Acts of Parliament, to the Statutes at Large of the Congress and into the myriad session laws and statute books of the several states, where could be found for our guidance no rationalizations, in written opinion or in treatise. Worse still, we were placed in the position of legislators or draftsmen facing prospectively a problem. Policies had to be determined, the appropriate devices discovered with which these policies could be best expressed and their administration and enforcement facilitated. It was our first contact with the distressing uncertainties involved in the constructive formulation of the law, our first attempt to cope with anticipated difficulties.

When, later, some of us worked with legislative bodies as so-called professional draftsmen, we were apt to blame him because he had not adequately taught us our trade. For we naively assumed that he had intended to make us skilled mechanics. But if Mr. Karl Llewellyn is right, in his preface to The Bramble Bush, in saying that a teacher must gain and not lose in retrospect, or be a failure, then Mr. Freund was a great teacher. For those seeds of attitude, of technique and awareness of difficulties have borne fruit in hundreds of minds that are still groping with the baffling processes of legal engineering, now grateful, however, for the master who gave the impetus and the direction.

Mr. Freund had been a political scientist before he became a law teacher. Perhaps that made him impatient with the mastery of judicial doctrine as an end in itself. Perhaps that is the explanation of his preoccupation with the functions of the statute law and of administration. Certain it is that he had little time for constitutional law, insofar as that subject was concerned with the existence of governmental power. Granted the power, he wanted to know how best to exercise it. Yet, when President Harper desired to build at the University of Chicago a purely scientific school of jurisprudence, Mr. Freund insisted upon the establishment of a sound professional school as a necessary basis. And in his work in Administrative Law and in Statutes, he never lost sight of the limitations upon his scope and method inherent in the student's professional viewpoint. On the other hand, these limitations were not his masters. As early as 1915 he was saying what was then heresy but has since become a slogan: that the effectiveness of the case method of legal instruction begins to decline about the middle of the student's second year. He longed to supplement with other methods and other materials. Before a meeting of the Association of American Law Schools, some ten years ago, he compared the wanderings of the social sci- 
entist through the trackless wilderness of fact and of official action with the smooth road of the law teacher, whose way was made clear, he laughingly asserted, when he had found the appropriate key number.

He lived to see the day when the emphasis in the law teaching world had shifted to the methods advocated and practiced by him fifteen years ago. And it was typical of his scientific mind that he then found himself on the defensive, distrusting the movement's high-pressure salesmanship, with its blare and its extravagant pretenses. He lived to see the Congress and most of the American state legislatures come to accept gratefully the services of legislative drafting agencies, only to regret that more of the draftsmen were not as expert as they were expected to be. He lived to see law school courses and the literature in Statutes gradually multiply, and suffered because for the most part his young colleagues in the field proved incapable of seeing the woods for the trees. Ernst Freund was one of the great juristic pioneers of America.

\section{THE WORK OF ERNST FREUND IN THE FIELD $\dagger$ OF LEGISLATION}

\section{ARTHUR H. KENT*}

$\mathrm{L}^{\mathrm{A}}$ APSE of time is a condition precedent to the proper evaluation of the contributions of Ernst Freund in the field of legislation. In his case as in the case of any great scholar and creative thinker, years must pass before that which is of enduring value and significance in his work can with certainty be determined. The judgment of one who for several years enjoyed the great privilege of colleagueship with him could scarcely escape the influence that the power and originality of his mind and the charm of his personality inevitably exerted. It seems safe to assert, however, that his influence lives after him. A brief enumeration of his activities and contributions in the field of legislation and allied fields will serve to indicate how extensive and varied they were.

In a life unusual for its great diversity of interests legislation and administrative law were the deepest and most enduring. Partly this was due to the character of his training, for he came into the law through the gateway of political science and with the background of a German university training. Partly it is attributable to an originality of mind and freshness of point of view which made the exploration of new fields more congenial to him than the further pursuit of beaten paths of legal scholarship. Moreover, his deep interest in social, economic and political data and points of view no doubt contributed to the focusing of his interests in public law, which has so many points of contact with the social

$\dagger$ A paper read at the annual meeting of the Association of American Law Schools, Chicago, Illinois, December, 1932.

* Professor of Law, the University of Chicago Law School. 
sciences. He early came to realize the dependence between mastery of legislative technique and understanding of social science data in the legislative process.

Dean Van Hecke has paid felicitous tribute to Professor Freund's outstanding gifts as a teacher, to the importance of his contributions in his chosen fields through the products of his creative scholarship, and his success in winning a place for Administrative Law and for the systematic study of the legislative process along with the judicial process in the curricula of leading American law schools. In addition some mention should be made of his long period of service as a member of the National Conference of Commissioners on Uniform State Laws. His distinguished service as a member of this body continued from his appointment by the Governor of Illinois in 1908 until his death. During this long period he missed not more than four or five of the rather lengthy annual meetings and participated actively in both the proceedings and discussions of these conventions and in the work of the committees. While he served as chairman or member of a number of committees, his services in connection with three of them are deserving of particular mention. The first of these was the Committee on Scope and Program, to which he belonged from I9I 5 to I927. This committee has a determining voice with regard to questions of policy, particularly the topics which shall be considered for uniform legislation. His broad knowledge of law and his studies and experience in statutory work and in the administration of law combined to assist this committee materially in reaching wise conclusions. The authorship of the report dealing in an exhaustive fashion with the future development and policy of the Conference, presented to and adopted by it in I923, was largely his. From I9I 5 on, save for one year, he was also a member of the Committee on Legislative Drafting. In this connection he formulated rules governing questions of form and style in the drafting of uniform acts. These rules were adopted by the Conference and are printed annually in its Handbook for the guidance of future draftsmen.

Professor Freund's principal contribution in the actual drafting of legislation arose out of his many years of service as a member of certain committees in the Social Welfare section of the Conference, in connection with acts relating to marriage and divorce, the guardianship of children, child labor, and narcotic drugs. He drafted an act intended to improve materially the legal position of illegitimate children and procured its adoption by the Conference in 1922, after defending it successfully against vigorous criticism at several meetings. This Act has now been enacted, with some slight changes, in eight states. In the drafting of this legislation Professor Freund worked in close co-operation with the Bureau of Child Welfare and other social agencies. He was likewise keenly interested in the Divorce Jurisdiction Act which he prepared and presented. Since its approval by the Conference in 1930 it has been enacted into law in at least one state. In addition to the above activities, he served at various times on such committees as Banks and Banking, Taxation, and Compacts and Agreements between States. 
Professor Freund was unremitting in his efforts to procure adoption of various uniform laws by the Illinois legislature. That his efforts, ably supplemented by the work of other members and friends of the Conference, were fruitful is indicated by the fact that fourteen of the uniform acts have been enacted into law in this state, thirteen of them since he became a member of the Conference.

Among his other public services which are worthy of note were the leading part which he played in the preparation of a new charter for the City of Chicago in the year 1905 and his participation in the work of the constitutional convention of I9r9-20 as an adviser on constitutional law. In this latter connection he drafted provisions which would have brought to the City of Chicago a large degree of autonomy in local affairs. These sections were adopted by the Convention only after the most vigorous and at times bitter attacks by various politicians and interested groups who sought to convey the impression that they were the work of an impractical idealist and academic theorist. By his success in repelling these attacks Professor Freund proved, if proof were needed, that his feet were upon the ground and that he was not lacking in a keen perception of the realities.

If only time can fully reveal the extent of his influence and the enduring values in his work, none will doubt the freshness and the stimulating qualities of his mind, the thoroughness of his scholarship, his high professional ideals, his strong sense of public responsibility, and his passion for social justice. When shall we see his like again?

\section{ECONOMIC ILUSIONS UNDERLYING LAW}

\section{DONATD R. RICHBERG*}

$T$ HE ultimate sanction of law making ${ }^{\mathrm{T}}$ rests upon the establishment of facts. The evidence presented in a court may or may not support the judgment entered; but if law making is to be effective, the judgment itself should be a fact. The judicial conclusion that Jones owes ten dollars to Smith may be founded in error. But the judgment will establish as a fact the indebtedness of Jones to Smith. In the higher realms of legislative and judicial law making, it becomes a matter of grave importance that legislators and judges shall not declare that to be a fact which is not a fact, or declare that to be fixed and established which is uncertain and unpredictable.

These preliminary observations may serve to introduce a brief criticism of the efforts of legislatures and courts to write economic illusions into law. There is, for example, hardly anything more difficult to determine than the "value" of property. But there is hardly any illusion more common than the notion that

* Member of the Chicago Bar.

" "The true view, as I submit, is that the law is what the judges declare . . . "Gray, Nature and Sources of Law (Ist ed. 1909), $\S 602$. 
things have intrinsic value and that, although market prices may rise and fall, at least those things which are commonly bought and sold always have a certain definite and ascertainable "value."

The constitutional provision against deprivation of property is one of the most important limitations on powers of government, and is a stalwart protection of individual rights. "Property," in legal definition, means the rights of an owner in a thing possessed; ; and it has been well held that a man is deprived of property not only by interferences with its physical possession, but by interferences with a reasonable exercise of his rights of ownership.

Unhappily the doctrine has developed in our jurisprudence that protection of property includes protection of the supposed intrinsic values of property. Therefrom has come an effort to make and establish law on the basis of an economic illusion - the illusion that a "value" is a durable fact and that the value of property is something which, having been ascertained at any particular time, can be legally established and made the foundation of legally enforceable rights. It is true that for exchangeable commodities a current market price can usually be ascertained from current market transactions. But to state a future price is to state an opinion - to indulge in speculation. Even an actual market price cannot be defined as a "fair" market price, because what is a fair market price will depend upon individual interests and upon social and economic theories and ethical concepts of infinite variety, which cannot be reduced by a legislature or a court to a formula for law making.

Therefore, when a court or a legislature begins to dabble with the idea of setting up something described as a "fair value" as the basis of law making, the law makers, however distinguished and wise, have undertaken the impossible task of establishing, as a legally authenticated fact, that which is not a fact. When a judicial robe is draped over a shadow, the shadow is not endowed with life. The judicial robe falls to the ground.

In that unhappy judicial error, entitled Smyth $v$. Ames, the court held that all utility rate regulations must be based upon "the fair value of the property being used." 3 No one has ever known, and no one will ever be able to ascertain, the "fair value" of any property. Only the omnipotence of Deity could decide what a man should "fairly" charge his fellow-men for his services, or for the use of any material thing in which he has what are called property rights.

There is an economic concept of value which means "power to command a price." A thing may have at a particular moment a certain market value determined by, and expressed in terms of, something else for which it may be exchanged. But the only factual basis for this value is the fact that the exchange

2 Branson v. Bush, 25 I U.S. 182 , I87 (I9I9); Block v. Hirsh, 256 U.S. I35, I65 (1920); Thompson v. Androscoggin Improvement Co., 54 N.H. 545, 55 I, 554 (1874); 2 Austin, Jurisprudence (5th ed. 1885), 795; 23 Am. \& Eng. Enc. Law, Property, 26I (r903).

3 "We hold, however, that the basis of all calculations as to the reasonableness of rates . . . . must be the fair value of the property being used . . . " Smyth v. Ames, I69 U.S. 466, 546 (1897). 
can be made. It may be a fair exchange, or a very unfair exchange. The common acceptance of a "fair value" is the current ratio of exchange. The "fair value" of the services of a human being in this day of misery, when twelve million willing workers are unemployed, may be accepted by some persons as one dollar per day or less. But a few years ago anyone who suggested that one dollar per day or less was the fair value of a day's work would have been generally derided. In the long view any person's idea of the fair value of a day's labor will depend upon his individual interests and upon his social and economic theories concerning desirable methods of production and distribution, and measures of the compensation which producers, distributors and others can and should receive.

In order to simplify a discussion of property values, it is well to observe at the outset that any general agreement upon the fair value of a day's labor is practically impossible. Next we should note that the actual value of a day's laborits exchange value in commodities-is utterly inconstant. Since the values of all large properties are based principally upon labor costs of infinite variety and mutability, it must be evident that it is quite impossible to arrive at any general or lasting agreement as to what is the fair value of any large property.

For a generation since the doctrine of Smyth v. Ames was announced, the courts and legislatures have been struggling hopelessly to make sense out of the requirement that the rates for public utility service should be based upon the fair value of the properties devoted to public use. Throughout the rising and falling markets from 1898 to 1929 , courts, commissions and legislatures struggled to solve the riddle which the Supreme Court of the United States in its unwisdom had propounded.

The Congress of the United States, in a noble effort to pay proper deference to the authority, if not to the wisdom, of the Supreme Court, enacted an elaborate law providing that railroad rates should be fixed so as to provide a fair return upon the values of railroad properties. 4 The Congress even had the temerity to pass a law requiring the Interstate Commerce Commission to ascertain and report the value of all property owned by railroads. The Congress also directed the Commission to consider everything under the sun which might aid in determining what values railroad properties had.5 As a result, for long years the Interstate Commerce Commission has struggled in vain to fix the values of railroad property. Just when the delusion of a Gargantuan Guess was about to climax these tremendous labors The Depression destroyed any hope of even self-deception. The valuation estimates accumulated for fifteen years became practically worthless over night.

${ }_{4}^{4}$ I Stat. 488 (r920), 49 U.S.C. § I5a (r927).

5 "Original cost . . . cost of reproduction new . . . depreciation . . . other values and elements of value . . . original cost of all lands . . . and the present value . . . history and organization [of operating corporations] .... increases or decreases . . . moneys received [from securities] . . . net and gross earnings . . . amount and value of any aid . . . donation." . . . etc. 4 I Stat. 624 (I922), 49 U.S.C. § Iga (I927). 
During this same period all over the land Public Utility Commissions have been struggling likewise to fix the values of hundreds of public utility properties. Many thousands of administrative proceedings have been conducted at the cost of millions of dollars in the pursuit of this great illusion. Many hundreds of litigations have moved with lame, reluctant feet through the lower courts and up into the Supreme Court of the United States, wherein the able and the dull, the brave and the timid have all sought in vain to solve the great riddle.

The Depression should prove even to the most dull and obstinate that the riddle of value can never be solved. It is difficult for those having faith in a beneficent Providence to understand why this economic calamity should have been visited upon the United States, and indeed upon the whole world. But perhaps it was necessary to teach mankind again the ancient lesson that physical properties have no intrinsic value; that all material values are in the nature of illusions; that the wealth of yesterday is gone tomorrow; that a factory or a railroad that cost ten million dollars yesterday may hardly' be worth the price of destruction today; that the assets of a huge bank described as "sound and seasoned securities," may shrink millions of clollars in a year or a month; and that all the "values" of material things upon which we so proudly rest our future hopes and which provide us with such a pleasant sense of security, may dissolve into vapor between sunset and sunrise.

The present writer reviewed various opinions of the Supreme Court on the subject of value in an article in January, r924, entitled "The Supreme Court Discusses Value";" and in another article in February, r927, entitled "TalueBy Judicial Fiat."' A few years later in arguing, as a perhaps unwelcome "friend of the court" in the O'Fallon case," he again sought directly", but in rain, to convince the court that it must reject the illusion that a "value" was a clurable. economic fact. Counsel for the great railroads of the country were claiming that the railroads had a "true value," which they described as "the economic equivalent of the property." They were asking the court to base its law making on the economic fallacy that articles and material things have "true values," or in the language of the economists "abiding intrinsic worth." The Supreme Court, despite the powerful dissents of certain of its members of notable economic and social intelligence, has not as yet rejected the unwholesome and unsound theories of "value" to which it has been so long committed. But in the light of the evidence of the last three years we may well wonder whether it is conceivable that the supreme judicial body of the nation can longer cling to theories which have not only been discredited, but have been made a counsel of pure folly by the logic of events.

In the Southwestern Bell Telephone case, 9 decided May $2 x$, I923, the majority opinion of the court was based upon a cloctrine stated in the following ex-

${ }^{6}{ }_{7}$ I Harv. L. Rev. $2 S_{9}$ (1923). i to Harr. L. Rev. $3^{67}$ (1927).

${ }^{*}$ St. Louis and O'Fallon Ry. Co. v. Enited States, 279 L'.S. $+^{6 r}$ (rgas).

9 Mlissouri ex rel. Southwestern Bell Tel. Co. v. Pub. Sers. Com.. 262 L.S. 2;6 (1022). 
traordinary sentence: "An honest and intelligent forecast of probable future values made upon a view of all the relevant circumstances is essential."

In the foregoing sentence the court rested the whole machinery of public utility rate regulation upon the requirement that the regulators attempt success in an undertaking in which no trader in the entire history of the New York stock exchange has been able to succeed. If any human being could make an honest and intelligent forecast of probable future values, he should be elevated to the position of supreme dictator of the economic welfare of the world. Of course, a good guesser can make an honest guess at the probable future price of a single article within a limited period. A professional gambler, with plenty of experience, may be able to make a better guess than an amateur at the numbers which will appear when the dice are rolled. But should the guesses of gamblers be sanctified as "honest and intelligent forecasts" and made the basis of law making?

At the time of the foregoing opinion the majority of the Supreme Court seemed possessed of the delusion that price levels, after grave fluctuations, were becoming stabilized; that a new and "relatively permanent price level" had been reached. In 1926 the Supreme Court handed down a majority opinion in the Indianapolis Water case, in which the previous requirement of an honest and intelligent forecast was reaffirmed in the following language: "There must be an honest and intelligent forecast as to probable price and wage levels during a reasonable period in the immediate future."

The requirement apparently was that future values should be forecast on the basis of forecasts of probable price and wage levels in the immediate future. Any genius who could make such forecasts would be given employment on his own terms by practically any large manufacturing concern, or any investment, banking or trading corporation able to capture his services from a swarm of eager competitors.

Throughout the two opinions just cited, persists the illusion of the court that there are such things as "relatively permanent price levels," upon which estimates can be based of probable future "values," in disregard of the obvious fact that even costs do not determine value and that, therefore, even stable material prices and wages would not provide a sound basis for estimating values. $^{\mathrm{x}}$ We may point out that the dissenting minority of the court has been amply justified by The Depression in its protest, which was expressed by Mr. Justice Brandeis in the Southwestern Bell Telephone case as follows: "But for the assumption that there will be a plateau (of prices) there is no basis in American experience."'xr

According to the unenforceable "law" which has not yet been rejected by the

1o In its earlier opinions the Supreme Court recognized economic realities: "Never was it held that the cost of a thing is the test of its value." C.C.C. \& St. L. Ry. Co. v. Backus, I5t U.S. 439,446 ( $\left.\mathrm{ISg}_{4}\right)$. "The value of property, generally speaking, is determined by its productiveness-the profits which its use brings to the owner." Monongahela Navigation Co. v. United States, I4S U.S. 3 I2, 328 (1893).

"Southwestern Bell Telephone Co. case, supra, note (9), at page $3 \circ 3$. 
Supreme Court, rates for all public utility service in the United States should be based today upon the value of the properties devoted to public use. If, in fact, the public utilities of the United States were today revalued on the basis of the actual present market values of their properties, it is unlikely that many public utility corporations could avoid bankruptcy. There can be no question that the great railroad systems of the country could not meet their aggregate fixed charges, if rates were based on the present market values of their aggregate properties. A reduction of the rates of other public utilities so that they would provide only the current fair return upon the present market value of their properties would bring about wholesale receiverships.

Throughout the period when the advocates of "reproduction cost" were overwhelming the advocates of "prudent investment," with profound and imposing opinions of the courts, reeking with legal and economic fallacies, it was the pleasant custom of those who sought to have public utility properties valued at two, three or four times the amounts of the investment in these properties, to assert cynically that, if there should come a great downward trend in price levels, the lawyers for the consumers would shift their ground and advocate reproduction cost valuations and the lawyers for the utilities would shift their ground and advocate the protection of investment. Today it appears that the lawyers for the utilities are quite generally shifting their ground as they prophesied. But it is to be hoped that the lawyers who represent the consumer or public interests will remain steadfast advocates of a sound method of public utility rate regulation and will not be lead astray and follow the will-o'-the-wisp of value. There can be no eventual benefit to either public or private interest in having law making based on economic illusions.

A value is a fluctuating ratio. ${ }^{\mathrm{ra}}$ The values of commercial properties result from their earning power. It will be necessary in the future to find some measuring stick to determine what earning power should be permitted to large, monopolistic properties, whether devoted to public utility service, or devoted to supplying other essential commodities and services. In this development of law, which must involve some public control over private profit-making, it is of the greatest importance that legislatures and courts shall not attempt to work out their solutions in minds beclouded with economic illusions concerning property "values." Equally important is it to exorcise legalistic notions that the preservation of property rights requires the preservation of artificially established property values, which should never be created, and which in the long run cannot be maintained by legislative or judicial fiat.

12 "Value is the effect in exchange of the relative social desire for compared objects expressed in terms of a common denominator." International Harvester Co. v. Kentucky, 234 U.S. 216, 222 (1913) (Opinion by Mr. Justice Holmes).

"The value of a commodity means in economics its power of commanding other commodities in exchange. It means the rate at which the commodity exchanges for others." Taussig, Principles of Economics, I, p. Ir 5 .

"The 'value' of a thing is always its value for the particular purpose, and in the particular conflict, in hand at the time of the valuation." 27 Col. L. Rev. 624 (I927). 


\title{
SURVIVAL OF THE ACTION FOR DEATH BY WRONGFUL ACT
}

\author{
ALvin E. Evans*
}

$\mathrm{A}_{\text {adequacies of Existing 'Wrongful Death' and Survival Legislation.". It }}^{\text {NOTE in a recent volume of the Harvard Law Review discusses the "In- }}$ fails to note one deficiency with which this note is concerned, viz., the failure in most jurisdictions to provide for the survival of wrongful death actions on death of the wrongdoer. It is stated in Johnson v. Farmer ${ }^{2}$ that survival in such cases is provided for by statute in only eight American jurisdictions.

Is it necessary in order that such an action may survive the death of the wrongdoer that the Lord Campbell's statute shall expressly so provide? There is a growing list of jurisdictions that have made an affirmative answer to this inquiry. ${ }^{3}$ The reason rather obviously is that there was no action for wrongful death at common law. Therefore, the survival statutes which provide for the survival of certain common law actions for a tort, e.g., for personal injuries, do not embrace it. That is to say, these survival statutes are strictly survival statutes. The death statute creates a new action which never accrued to the decedent and not having existed it cannot be said to survive unless there is specific provision therefor. There are six states that provide that all actions shall survive, viz., Connecticut, Iowa, Louisiana, Mississippi, Montana, and New Hampshire. 4 No case raising the question of survival of the action for wrongful death in any of these save Montana has been found. One should expect that these statutes alone are insufficient for that purpose, as the action for

* Dean of the University of Kentucky College of Law.

${ }^{2} 44$ Harv. L. Rev. 980 (193I).

289 Tex. 6ro, 35 S.W. 1062 (I896).

3 Davis v. Nichols, 54 Ark. 358, I5 S.W. 880 (r89I); Clark v. Goodwin, I70 Cal. $527,1_{50}$ Pac. 357 , L.R.A. I9r6 A, Ix43 (I9r5); Hamilton v. Jones, I25 Ind. I76, 25 N.E. I92 (I890); Demczuk v. Jenifer, $x_{38}$ Md. 488 , Ir 4 Atl. 47 I (I92I); Green v. Thompson, 26 Minn. 500,5 N.W. 376 (I880); Bates v. Sylvester, 205 Mo. 493, x04 S.W. 73 (I907); Hegerich v. Keddie, 99 N.Y. 258 , x N.E. 787 (1885); Willard v. Mohn, 24 N.D. 390 , I39 N.W. 979 (rgr3); Russell v. Sunbury, 37 Ohio St. 372 (r88r); Moe v. Smiley, x25 Pa. St. r36, I7 Atl. 228 (I889); Carrigan v. Cole, 35 R.I. 162, 85 Atl. 934 (I9I3); Johnson v. Farmer, 89 Tex. 610, 35 S.W. 1062 (I896); Needham v. Grand Trunk Ry. Co., 38 Vt. 294 (I865); Rinker v. Hurd, 69 Wash. 257, r24 Pac. 687 (Igr2); Kranz v. Wisconsin Trust Co., I55 Wis. 40, I43 N.W. I049 (I9I3); (A case in Virginia, Beaver v. Putnam, xro Va. $7 x_{3}, 67$ S.E. 353 (rgro) is sometimes cited mistakenly as being in accord with this rule. The mistake consists in assuming that the statute does not provide that action for wrongful death shall survive the death of the wrongdoer. The statute expressly provides for such survival. In that case there was no survival because the murderer committed suicide, dying before the murdered person died. Thus it was held that no cause for wrongful death ever accrued, since the cause of action, the wrongful death, had not occurred when the wrongdoer died and a cause of action cannot for the first time arise against a dead man.)

4 See 29 Mich. L. Rev. 969, 972 (I93I). 
wrongful death is not a revived action. In Montana the action survives because there is express provision to that effect. 5

Two states, Illinois and Kentucky, ${ }^{6}$ have held that the action will survive under the survival statute. In Illinois the survival statute provides generally for the survival of actions for personal injuries ${ }^{7}$ and therefore includes actions for assault, but it makes no express provision for the survival of wrongful death actions. Illinois meets the contrary decisions of other states by the assertion that their survival statutes do not affect personal injuries while the IIlinois statutes make specific provision therefor. This seems to imply that the action for wrongful death is a revived action rather than one newly created. The court, however, was clearly mistaken as to the statutes in several jurisdictions named, since several provided for survival in case of personal injuries.

A recent Kentucky case ${ }^{8}$ holds that the action for death by wrongful act arising from an assault (murder) survives the death of the wrongdoer, although actions for assault are specifically excepted from those actions that survive for injuries to the person. This peculiar result is reached: that if the assault produces bodily injuries only and the wrongdoer happens to die before judgment against him is obtained there is no recovery therefor, but if the assault results in death there is a recovery although the Kentucky Lord Campbell's Act contains no statement about survival. It is seen, therefore, that the Kentucky decision is even more difficult to reach and goes much further than the Illinois decision. We deduce from the Illinois decision that the action for wrongful death by assault survives because actions for assault not resulting in death survived.

The Kentucky court gets around this embarrassment by declaring that the action is not for the assault and death of the decedent but for the injury done to those for whose benefit the action is created. Is this a valid reason? The court does not disturb itself with the more or less metaphysical distinctions between the cause of action and the subject matter of the action. In order for an action for wrongful death to survive it does not argue $(a)$ whether there must be a provision in the creating statute for survival or $(b)$ whether the wrongful death action is a new creation or is merely a revived action which survives if there is a general survival statute. It has been held, however, in other cases that a new action was created by statute. Obviously, neither alternative will reach the conclusion which has been adopted and so a third theory is in order.

It seems clear that the injury for which the action is brought is the taking of the life of the decedent. The consequence of this act is the loss of support which

s Anderson v. Wirkman, 67 Mont. I76, 21 5 Pac. 224 (1923). The same effect was given to the statute in North Carolina. See Collier v. Arrington, 6x N.C. $35^{6}$ (I867).

${ }^{6}$ Devine v. Healey, 24I Ill. 34,89 N.E. 25I (Igog); Morehead v. Bittner, Io6 Ky. 523, 50 S.W. 857 (I899); Merrill v. Puckett, 93 S.W. 912 (Ky. I906); Hunt v. Mutter, 238 Ky. 396, $38 \mathrm{~S} . W .(2 \mathrm{~d}) 215$ ( $193 \mathrm{I})$.

7 Cahill's Ill. Rev. St. of 1931, c.3, \$125.

${ }^{8}$ Hunt v. Mutter, silpra n. 6. 
the widow and children suffered and therefore the Kentucky court permits an action for consequential damages. This approach to a solution had been suggested in other jurisdictions only to be met by the response that an action for consequential damages does not come within the survival statute. 9

The Kentucky decisions seem indefensible because (a). the wrongful death statute does not provide that the action shall survive the death of the wrongdoer, (b) the survival statute applies to injuries to the decedent and excludes actions for assault, and (c) the damages to the surviving widow are consequential in that a statute is required to provide any action at all. In other words, the statute does not provide for the survival of an action for personal injury to the widow because there was none. Further, the survival statute antedates by about forty years the death statute.

It has been held in Virginia ${ }^{x o}$ that even if there is a statute providing for the survival of an action for wrongful death, there is no cause of action if the wrongdoer dies prior to the death of the injured person. Here is another deficiency. Technically, it would seem that a cause of action must accrue against a person while alive if at all. Yet the wrongdoer had as effectively committed an act which was to cause death as if he were still alive when the death he caused occurred. The reason for providing a right to sue in such case is identical with the right to sue in the other case, viz., the duty to provide for the support of the bereft family. Morally, it makes no difference whether the murderer died five minutes before or five minutes after the death of the murdered person.

$\mathrm{It}$ is suggested, therefore, that actions for wrongful death should by specific provision of statute survive the death of the wrongdoer and that the wrongful act which ultimately may cause the death of a person should be made actionable against the wrongdoer's personal representative even though he may have died before his victim.

9 Demczuk v. Jenifer, supra n. 3 (Murder. Murdered woman died before suit was brought by the husband of decedent. The cause of action pleaded was the husband's loss of the wife's services as a result of the wrongful act of another. Held, the term "injuries to the person" means injuries causing physical pain, discomfort or disability which occasions loss or damage either to such person or to any person entitled to the benefit of services of the injured person.); Moe v. Smiley, supra n. 3 (Murder. Defendant committed suicide three hours later. The cause of action is the wrong to the husband, not the wrong to his widow.); Kranz v. Wisconsin Trust Co., supra n. 3 (Negligent injury resulting in death. Defendant died after action was instituted. Held there is a difference between the survival of a cause of action and the survival of a liability. Plaintiff had no property right in life of decedent's husband. It is the property right of decedent to which the statute applies.)

ro Beaver v. Putnam, supra n. 3 . 


\title{
WHEN IS A SUICIDE COMPENSABLE UNDER A WORKMEN'S COMPENSATION STATUTE?
}

\author{
RALPH S. BAUER*
}

\section{$T$} HE facts on which the question of compensation for a suicide under a workmen's compensation statute arise are, in broad outline, as follows: the employee, after receiving injuries arising out of and in the course of the employment, finding convalescence slow or difficult, commits suicide. In some of these cases, the facts indicate with sufficient clearness that he had, at the time of killing himself, complete control over his actions, or, to put it another way, that, at the time, his acts were volitional. In other cases, the facts seem to indicate clearly enough that he was, at the time of the suicide, so completely insane as to have no volition. In some of this latter class of cases, the clearly indicated insanity has, as one of its manifestations, an uncontrollable impulse to commit suicide.

Here, as in all other fields in which human conduct is to be judged by more or less uncertain and relative standards and not by set rules, and in which there is often comparative uncertainty as to what the facts really are, there naturally exists a considerable border-land of cases of which the final disposition is hardly predictable. Probably the disposition of a close case by the board is less easily predictable than is the result of an appeal to the courts from an award or a refusal of an award by the board, for, in such a case, the court is likely to follow the finding of facts by the board, just as in a common law case it would follow the finding of facts by the jury if there is some evidence to sustain the finding.

The key to the situation seems to be in the question whether the decedent exercised volition in committing suicide, and this should be true, whether the formula used in a particular case emphasizes as essential to recovery non-volition or insanity or an uncontrollable impulse. Insanity is important only as it destroys the power of true volition to die and therefore makes it a fact that decedent's suicide was not a volitional act. An uncontrollable impulse is important only as a driving force that has impelled the decedent into the suicidal act without the exercise of any true volition. Looking at the different formulae in the abstract, one might come to the conclusion that whether proof of non-volition of the decedent or of uncontrollable impulse or of both is stated as a requisite of claimant's case, in the great majority of cases, probably would make no difference; but, inasmuch as a general state of non-volition in the mind, especially in a well developed case of insanity, is a thing often so distinctly evidenced by objective manifestations as to be fairly susceptible of proof, while an uncontrollable impulse is likely to be a thing so strictly subjective as to give little or no objective manifestation prior to the suicidal act and therefore likely to be unsusceptible of proof, probably a formula directly making volition the pivotal

* Professor of Law, De Paul University. 
point upon which to decide the case is preferable to a formula making the case turn upon uncontrollable impulse. It is of course true that the very reason for talking about uncontrollable impulse is that the suicide upon uncontrollable impulse is not a volitional suicide; but, because of the subjective approach through the "uncontrollable impulse" formula, it would seem that industrial boards may find it more difficult to justify in their own minds an award to the claimant under this formula than under the formula stressing volition. It may be comparatively easy to adduce some objective proof that the decedent was so insane that he was incapable of entertaining any volition, so that there is some proof to sustain an award; but it may be somewhat more difficult to find any proof that the decedent actually had an uncontrollable impulse to commit suicide, for the fact of uncontrollable impulse lies in the field of the subjective, which is not so easily penetrable by proof.

In general, in workmen's compensation cases, courts seem inclined to follow loosely, with perhaps a greater liberality to plaintiff, the general principles of the common law as to causation and of inclusion of damage within or exclusion from the operation of the rule of law invoked by the plaintiff, just as they have done in cases brought under wrongful death statutes. ${ }^{x}$

In one case, ${ }^{2}$ a board's award of compensation for suicide was permitted by

I Daniels v. New York, New Haven \& Hartford R. Co., I83 Mass. 393,67 N.E. 424, 62 L.R.A. 75I (x903), is a wrongful death case in which recovery was refused because the uncontroverted evidence tended to show that decedent "with deliberate purpose, planned to take his own life," that he had "an understanding of the physical nature and effect of his act," and that he had a "willful and intelligent purpose to accomplish it." This case is often cited and followed in workmen's compensation cases. See Tetrault's Case, 278 Mass. 447 , I80 N.E. ${ }_{23} \mathrm{~T}$ (x932).

${ }^{2}$ Sinclair's Case, 248 Mass. 4r4, r 43 N.E. 330 (I922).

For a criticism of Sinclair's Case, see article by the present writer, Suicide as Intervening Cause in Workmen's Compensation Cases as Compared with Suicide in Cases of Wrongful Death, 5 Boston Univ. L. Rev. 228 (I925). See also article, Comment on Professor Bauer's Article, Causation and Suicide, by Professor John E. Hannigan, 5 Boston Univ. L. Rev. 233.

In the original article at p. $23 \mathrm{I}$ the writer has said: "There seems to be no reported case in which the recovery has been allowed under a wrongful death statute, where so clearly volitional a suicidal act intervened as in Sinclair's Case. But, when one considers the purposes of the workmen's compensation acts and the tendency of courts not to apply strictly the common rules of proximate cause to these cases, it is not surprising that compensation is awarded in some cases in which the chain of causal connection seems weak. However, it is submitted that the opinion in Sinclair's Case goes much farther than the purposes of workmen's compensation acts justify. According to the report of the case, the evidence tends to show that the deceased committed suicide by intelligent, understanding, slow, and deliberate self-starvation. This was not an unconscious or involuntary act induced by the injury that had occurred in the course of his employment. Can the purposes of these statutes include compensation for death under such circumstances? The purposes of these statutes are social and economic. The primary social and economic purpose is to make happier and economically more stable the condition of the worker. Secondarily, it is purposed that this betterment of conditions will lead to greater efficiency in laborers. With these purposes in view it is deemed just to compel an industry to pay, as a part of its current expenses, compensation for such injuries as arise out of and in 
the court to stand, in the face of the finding by the board that decedent had refused food during a long period and had finally starved himself to death. Here, apparently, was a clear case of volitional suicide; but this is not the usual disposition of such cases, and the same court has recently seemed to evince a change of heart without any allusion whatever to its earlier aberration from the beaten path. ${ }^{3}$

In a recent case in the New York Appellate Division, ${ }^{4}$ the court said:

"The Industrial Board has found, upon competent supporting evidence, that the deceased employee, as the result of accidental injuries sustained by him in

course of the employment. It is submitted that no purpose of the act is served by granting compensation in such a case as Sinclair's. The assurance to the laborer that his dependents will receive compensation if he consciously and willfully starves himself to death after an injury, is not such a comfort to him as to increase his happiness or his deficiency; nor does it seem economically sound to compel an industry to pay for a willful suicide of an employee."

At p. 237 in Professor Hannigan's article referred to above, the following interesting queries are put: "May not a court, taking man as he is, permit a jury to consider the deprivation of or injury to his normal understanding or will power, resulting from a physical injury, as analogous to a progressive condition which may be the cause of further development of injury? The will to live, the will to resist evil suggestion; the power to fight against despair,-are they anything more than shields, powers of protection? When a man is wrongfully deprived of them, are not the consequences of such deprivation fairly in the chain of causation?"

The late Dean James Parker Hall, in a letter dated December 23, I925, addressed to the present writer, in regard to the above-mentioned article on "Suicide as Intervening Cause in Workmen's Compensation Cases," said: "I agree with your conclusion, which is also supported by the Scotch case of Malone v. Cayer, Irvine \& Co., 45 Sc. L.R. 35I. When the employee commits suicide when so insane, as to have no real volition, I agree that the Compensation Act should apply. Otherwise I do not think his death was in its policy. I should disagree with the Scheffer Case [Scheffer v. Washington City, etc. St. Ry. Co., to5 U.S. 249, 26 L. Ed. I070 (I88I), a wrongful death case], assuming the insanity there to deprive the injured person of his volition." Dean Hall seems to have considered volition or non-volition the proper test. On the whole, it would seem that no better test can be found, either in the cases of wrongful death or in those of workmen's compensation.

3 Tetrault's Case, 278 Mass. 447 , 180 N.E. 23x (x932). Here the employee received an injury December 30 , 1929, and was paid compensation until his death. He died January 20, I930. His widow claimed compensation for his death. The Industrial Accident Board found that the employee met his death by jumping from a bridge into the Connecticut river, and that his death was causally connected with conditions due to his injury, and awarded compensation. The superior court entered a decree whereby it ruled that the evidence did not warrant a finding that the death was "causally related to any injury arising in and out of the course of his employment," and dismissed the claim. The supreme judicial court affirmed the decree of the superior court, saying: "The testimony above recited and the other evidence in the case, though tending to show that the employee's mind was disordered when he committed suicide, did not warrant a finding that he took his own life 'through an uncontrollable impulse or in a delirium of frenzy without conscious volition to produce death, having knowledge of the physical consequences of his act.' "Without mention of Sinclair's Case, supra, note 2, the court here reverts to the earlier tests of uncontrollable impulse and non-volition, used in Sponatski's Case, 220 Mass. 526, I08 N.E. 466 , L.R.A. I916A, 333 ('915).

4 Konieczny v. Kresse Co., Inc., 234 App. Div. 517 , 256 N.Y.S. 275 (1932). 
his employment, became insane, due to which insanity he committed suicide as the result of an uncontrollable impulse and without conscious volition, and that said death unavoidably resulted from the said accidental injuries. There is, therefore, nothing to sustain appellants' contention of lack of causal relation between the injuries and death."

In a Vermont case, 5 the court said:

"It is held that when the insanity resulting from an accident ends in a suicide which is the result of an uncontrollable impulse or in a delirium of frenzy, and without conscious volition to produce death having knowledge of the physical consequences of the suicidal act, there is a direct and unbroken causal connection between the accident and the death, and compensation therefor is to be awarded. But when the suicide is the result of a voluntary, willful choice, with knowledge of the purpose and physical effect of the act, a new and independent agency intervenes, breaks the chain of causation, and compensation is to be denied. In compensation cases, the rule is the same as in negligence cases, as is shown by the Sponatski Case."

To a great extent, workmen's compensation decisions in general seem to be swayed by general common law principles of "causation" and of "intervening cause," $"$ and it is only natural that this should be as true of suicide cases as it is of cases of personal injuries to claimant. There are, however, some noticeable deviations from those principles. ${ }^{8}$

5 McKane v. Capital Hill Quarry Co., Ioo Vt. 45, I34 Atl. 640 (1926).

${ }^{6}$ Supra, n. 3 .

7 In Baker v. State Industrial Commission, I28 Ore. 369, 274 Pac. 905 (I929), the court, in allowing compensation, follows substantially one of the formulae of proximate cause often recited in the decisions of negligence cases. See also Polucha v. Landes, 60 N.D. I59, 233 N.W. 264 (I930); and Continental Casualty Co. v. Industrial Commission, 75 Utah 220, 284 Pac. 313 (1929).

${ }^{8}$ In some of the cases in which compensation has been allowed it seems that, either as to causation 'or as to certainty of proof, courts have been much less rigid in their requirements of plaintiffs than at common law. In Wilder v. Russell Library Co., Io7 Conn. 56, I39 Atl. 644, 56 A.L.R. 455 ( 1927 ), claimant's decedent, a young woman, was a librarian employed by defendant. She worked very hard as librarian and put much additional strain upon herself by work as president of the State Library Association and for conventions. These outside activities were for the purpose of benefiting the library and herself. Through overwork, she became insane and committed suicide. The decedent was subject by heredity to a predisposition of mental trouble. The commission had reached the conclusion, based on facts, that the death arose out of and in the course of her employment. This conclusion was sustained by the trial court and the supreme court. When one considers the uncertainty of proof of the causal relation in the case as reported, one wonders whether any such result would have been reached in an action brought under a wrongful death statute for negligently causing death of a decedent, a type of case in which the courts more certainly and consistently follow common law principles of causation.

In Travelers' Insurance Co. v. Peters, 3 S.W. (2d) 568, 57 (Tex. Civ. App. 1928), the court held that a petition for compensation for death of an employee was not demurrable because it 
To allow recovery of compensation for a clearly volitional suicide would seem to be going beyond the purpose of the workmen's compensation statutes, and it would probably encourage suicide in some cases. Furthermore, it would be an interesting question whether a statute in terms allowing compensation for volitional suicide would be constitutional.

Whatever formula is used, it would seem that the key to workmen's compensation cases in which the claimant seeks compensation for suicide is to be found in the question, "Did the claimant's decedent commit suicide without any real volition, as a result of an injury that is compensable under the statute?"

failed to allege that the accident was the proximate cause of the death, where the petition showed by clearest inference that the injuries sustained were the efficient, exciting, or contributory cause of death. 